\title{
19. ASTRONOMICAL CALIBRATION OF CYCLE STRATIGRAPHY FOR SITE 882 IN THE NORTHWEST PACIFIC ${ }^{1}$
}

\author{
Ralf Tiedemann ${ }^{2}$ and Gerald H. Haug ${ }^{3}$
}

\begin{abstract}
An astronomically calibrated stratigraphy is generated for Site 882 over the last $4 \mathrm{~m} . \mathrm{y}$. based on fine tuning of GRAPE (gamma-ray attenuation porosity evaluator) density oscillations in the orbital precession band to the summer insolation at $65^{\circ} \mathrm{N}$. This resulted in an independent calibration of the magnetic susceptibility record. The tuning improved the variance density over all the main orbital frequencies for both the GRAPE density and the magnetic susceptibility records and shows high coherencies with the summer insolation record, as indicated by cross-spectral analysis. Cross-spectral analysis between the GRAPE density and the magnetic susceptibility (indicative of the input of ice-rafted debris at Site 882) indicates an in-phase relationship over the main orbital frequencies.

Precessional periods dominate the GRAPE density spectrum during the last 1 m.y. In contrast, the magnetic susceptibility record was dominated by the 100-ka and 41-ka cycles during the last $1 \mathrm{~m} . \mathrm{y}$. This suggests that the magnetic susceptibility record via the input of ice-rafted debris is mainly controlled by changes in ice volume, whereas the GRAPE density spectrum might have a strong overprint of additional forcing mechanisms that follow the precessional period. The response to precessional forcing decreased from 1 to $2.7 \mathrm{Ma}$ and increased again between 2.7 and $4 \mathrm{Ma}$.

The tuned stratigraphy at Site 882 can be directly compared with other tuned records for further paleoceanographic and paleoclimatic investigations within the error limit of a few thousand years that result from the unknown phase lag in the frequency band between the GRAPE record and the orbital record.
\end{abstract}

\section{INTRODUCTION}

One of the major advances in paleoceanography and paleoclimatology in the past decade has been the discovery that orbitally induced changes in solar radiation strongly influence variations in paleoceanographic proxy records. This has resulted in the development of an astronomically calibrated time scale for the last 5-6 m.y. (Shackleton et al., 1990, 1995; Hilgen, 1991; Tiedemann et al., 1994). The benthic oxygen isotope records monitor global ice-sheet variations and changes in deep water temperature (Tiedemann et al., 1994). It has been shown that ice volume is directly linked to astronomical forcing and lags the Earth's insolation by $5-8$ k.y. (Imbrie and Imbrie, 1980). Other proxy records, as well as oxygen isotopes, also reflect astronomical forcing. For example, Shackleton et al. (1995) "tuned" the GRAPE sediment density record at Site 846 in the central Pacific, and Tiedemann et al. (1994) used the dust flux record at Site 659 off northwest Africa as independent parameters to generate the astronomically calibrated $\delta^{18} \mathrm{O}$ stratigraphy. They found along with Hilgen (1991) that the magnetic boundaries of the last 6 m.y. are $6 \%-8 \%$ older than the ages of the conventional time scale (Berggren et al., 1985).

At northwest Pacific Site 882, it is impossible to obtain a highresolution isotope record because of a lack of carbonate in many intervals of the sediment record (Haug et al., this volume). Two continuous and high-resolution proxy records are available, however, which can be used to generate an astronomically calibrated time scale. First, the magnetic susceptibility record at Site 882 reflects terrigenous input dominated by ice-rafted debris (IRD) since the major onset of Northern Hemisphere glaciation at $2.7 \mathrm{Ma}$. Second, the GRAPE density record monitors the changes in sediment composition caused by variations in biogenic opal productivity, carbonate productivity and dissolution, and IRD input (0-2.7 Ma).

\footnotetext{
'Rea, D.K., Basov, I.A., Scholl, D.W., and Allan, J.F. (Eds.), 1995. Proc. ODP, Sci. Results, 145: College Station, TX (Ocean Drilling Program).

${ }^{2}$ GEOMAR Forschungszentrum für Marine Geowissenschaften, Wischhofstrasse 1-3, D-24148 Kiel, Federal Republic of Germany.

${ }^{3}$ Geologisch-Paläontologisches Institut, Universität Kiel, Olshausenstrasse 40. D-24098 Kiel, Federal Republic of Germany.
}

In this paper, we present an astronomically calibrated stratigraphy for Site 882 for the last 4 m.y. based on fine tuning of the oscillations in the precession frequency band of the GRAPE density record to the summer insolation at $65^{\circ} \mathrm{N}$.

\section{METHODS AND DATABASE}

The magnetic susceptibility and the GRAPE density records are based on shipboard data (Rea, Basov, Janecek, Palmer-Julson, et al., 1993). Continuous measurements of both records were taken in Holes $882 \mathrm{~A}$ and $882 \mathrm{~B}$. Data spacing was approximately $4-6 \mathrm{~cm}$ for the last $2.73 \mathrm{~m} . y ., 10-15 \mathrm{~cm}$ in deeper sections for the magnetic susceptibility record, and $1-3 \mathrm{~cm}$ for the GRAPE density record. In both records, ash layers were deleted "on paper" based on the barrel sheet descriptions.

The high-resolution magnetic susceptibility and GRAPE density records from Holes $882 \mathrm{~A}$ and $882 \mathrm{~B}$ were spliced to obtain a continuous composite record for the last 4 m.y. In general, our depth correlation between both holes is based on the composite depth sections reported by the Leg 145 shipboard party (Rea, Basov, Janecek, Palmer-Julson, et al., 1993). However, if the core recovery exceeded the maximum recovery of $9.5 \mathrm{~m}$, we corrected the sediment depth by compressing such cores "on paper" back to $100 \%$ core recovery (Table 1). This minor revision resulted in a general reduction of the composite depth (mbsf c.d.) compared with the previous model defined by Rea, Basov, Janecek, Palmer-Julson, et al. (1993) and the removal of overlapping sections between succeeding cores from the same hole. Below 297.13 mbsf c.d. (base of Core 145-882A-28H, equal to $4.16 \mathrm{Ma}$ ), no composite depth is available and the sediment record is probably discontinuous because of a slight loss of sediment at core breaks.

The age of the magnetic susceptibility and GRAPE density records were initially interpolated from five magnetic reversal age control points (Table 2 ) which are based on the astronomically calibrated time scale from Shackleton et al. (1990) and Hilgen (1991): (1) the Brunhes/Matuyama boundary, (2) the Top Olduvai, (3) the Matuyama/Gauss boundary, (4) the Gauss/Gilbert boundary, and (5) the Top Cochity. For the last 2.6 m.y., a clear identification of the magnetic reversal boundaries was possible. However, between 106 mbsf c.d. and 333 mbsf c.d., the placement of magnetic reversals vs. 
Table 1. Composite depth sections for Site 882 .

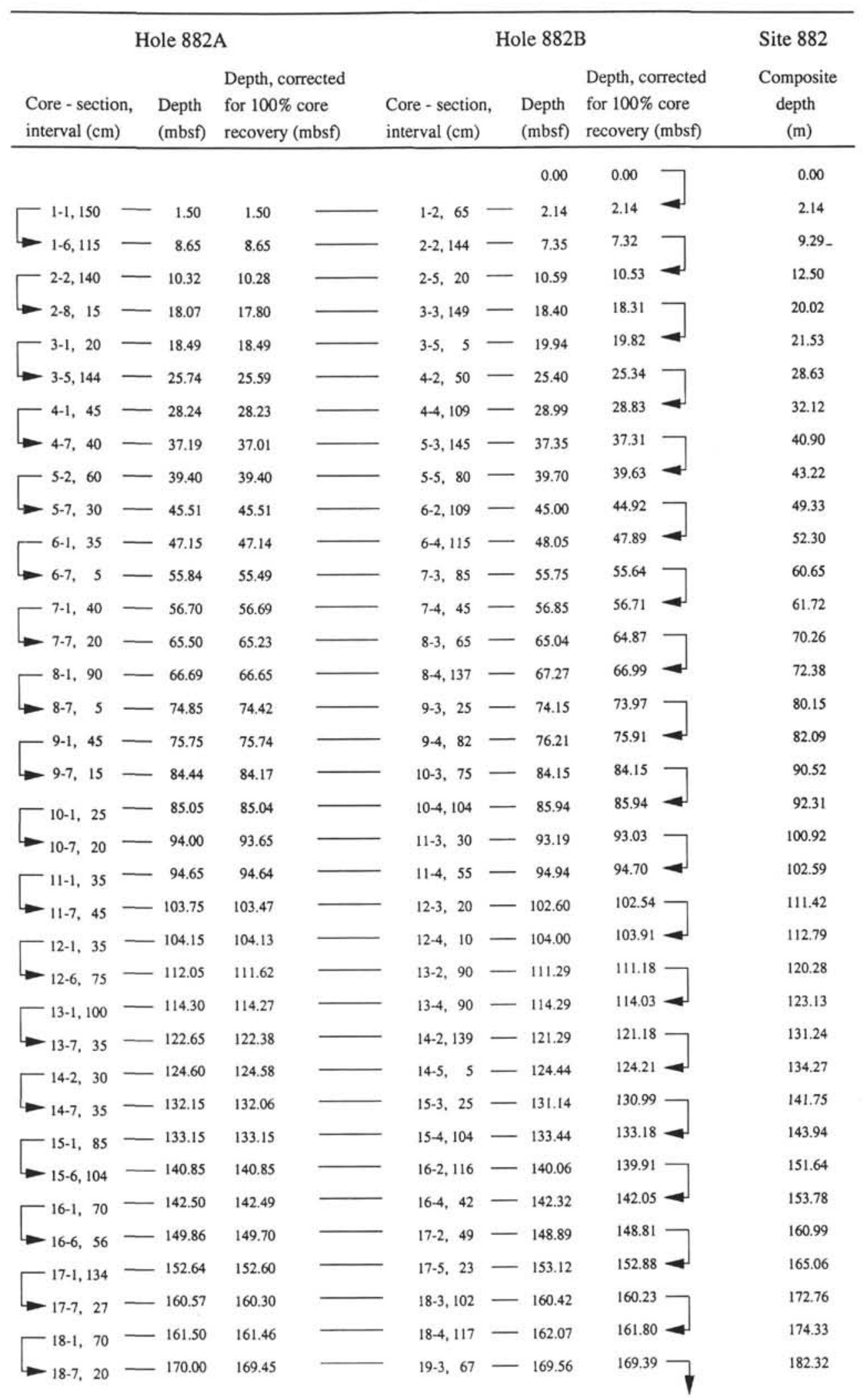

Note: Arrows indicate switch points based on between-hole correlations. Correlation is based on magnetic susceptibility and GRAPE data. 
Table 1 (continued).

\begin{tabular}{|c|c|c|c|c|c|c|c|c|}
\hline & & ole 882 & & & & ole $882 B$ & & Site 882 \\
\hline $\begin{array}{l}\text { Core - section } \\
\text { interval }(\mathrm{cm})\end{array}$ & & $\begin{array}{l}\text { Depth } \\
\text { (mbsf) }\end{array}$ & $\begin{array}{l}\text { Depth, corrected } \\
\text { for } 100 \% \text { core } \\
\text { recovery (mbsf) }\end{array}$ & $\begin{array}{l}\text { Core - section, } \\
\text { interval }(\mathrm{cm})\end{array}$ & & $\begin{array}{l}\text { Depth } \\
\text { (mbsf) }\end{array}$ & $\begin{array}{l}\text { Depth, corrected } \\
\text { for } 100 \% \text { core } \\
\text { recovery (mbsf) }\end{array}$ & $\begin{array}{l}\text { Composite } \\
\text { depth } \\
\text { (m) }\end{array}$ \\
\hline $19-2,20$ & 一 & 172.00 & 171.93 & $19-6, \quad 1$ & - & 173.40 & $173.04 \square$ & 185.97 \\
\hline$-19-7,23$ & - & 179.53 & 179.18 & $20-3, \quad 9$ & - & 178.48 & $178.29-$ & 193.22 \\
\hline $20-1,27$ & - & 180.07 & 180.07 & $20-4,51$ & - & 180.40 & 180.10 & 195.03 \\
\hline $20-6,140$ & 一 & 188.71 & 188.71 & $21-3, \quad 10$ & - & 188.00 & $187.83-$ & 203.67 \\
\hline $21-1, \quad 14$ & - & 189.44 & 189.43 & $21-3,98$ & - & 188.88 & 188.66 & 204.50 \\
\hline$-21-6,135$ & - & 198.16 & 197.68 & $22-2,65$ & - & 196.54 & $196.44-$ & 212.75 \\
\hline$-22-1, \quad 4$ & - & 198.84 & 198.84 & $22-7, \quad 6$ & - & 203.45 & 203.02 & 219.33 \\
\hline - $22-6,126$ & - & 207.56 & 207.10 & $23-2, \quad 26$ & - & 205.65 & 205.57 & 227.59 \\
\hline$-23-1,27$ & - & 208.57 & 208.56 & 23-3, 99 & - & 207.89 & 207.70 & 229.72 \\
\hline$-23-7,80$ & - & 218.10 & $217.57 ?$ & $23-7,50$ & 一 & 213.40 & $212.95 ?$ & 238.73 \\
\hline$-24-1,61$ & - & 218.41 & 218.38 & $24-3,72$ & - & 217.11 & 216.92 & 242.70 \\
\hline$-24-7,37$ & - & 227.17 & 226.70 & $25-1,91$ & 一 & 223.81 & 223.77 & 251.02 \\
\hline - $25-1,47$ & - & 227.76 & 227.74 & $25-3,117$ & - & 227.07 & 226.87 & 254.12 \\
\hline$-25-7,20$ & - & 236.50 & 236.15 & $26-3,110$ & 一 & 236.50 & 236.28 & 262.53 \\
\hline$[26-1,42$ & - & 237.22 & 237.20 & $26-4, \quad 9$ & - & 236.98 & 236.73 & 262.98 \\
\hline$=26-7,47$ & - & 246.26 & 245.79 & $27-2,131$ & - & 244.71 & $244.68 \square$ & 271.57 \\
\hline$[27-1,99$ & 一 & 247.29 & $247.25 ?$ & $27-4,135$ & - & 247.75 & $247.69 ?$ & 274.58 \\
\hline$=27.7 .45$ & - & 255.75 & 255.39 & $28-3,46$ & 一 & 254.86 & $254.76 \square$ & 282.72 \\
\hline T28-1, 15 & 一 & 255.95 & $255.94 ?$ & $28-6,117$ & - & 260.07 & $259.82 ? \square$ & 287.78 \\
\hline
\end{tabular}

depth remained uncertain because the signal of the natural remanent magnetization was too low and the results became noisy and inconsistent (Rea, Basov, Janecek, Palmer-Julson, et al., 1993). Significant magnetic reversals again became common below 333 mbsf c.d., which were assumed to represent, on the basis of magnetic susceptibility correlations with Site 884 (Fig. 1), the lower three normally magnetized events of the Gilbert Chron. Furthermore, the correlation between the magnetic susceptibility records enabled us to narrow the range of uncertainty in the depth placement of the following reversal boundaries: Top Kaena, Top Mammoth, Gauss/Gilbert, and Top and Base Cochity (Fig. 1). Table 2 gives the ages and depths to recognizable reversal boundaries at Site 882 .

For the astronomical calibration, we used the standard tuning techniques of Imbrie et al. (1984). For time-series analysis, the age of each data point was estimated by linear interpolation between agedepth control points. We then interpolated each record at constant $3-k . y$. intervals. After the data had been linearly detrended the variance density spectrum was estimated and the data were then filtered at the dominant frequency bands. For the tuning procedure, we used the astronomical solution of Berger and Loutre (1991) for the last 5 m.y. We tuned the precession-related oscillations of the GRAPE density record to the summer insolation at $65^{\circ} \mathrm{N}$.

\section{ASTRONOMICAL CALIBRATION OF THE TIME SCALE (0-4 MA)}

A first attempt at spectral analysis after linear interpolation between the initial age control points shows that both GRAPE density and magnetic susceptibility oscillations were broadly related to vari- ations in orbital periodicities (Fig. 2). The untuned GRAPE density and magnetic susceptibility records show a high response to the eccentricity (400 and $100 \mathrm{ka}$ ), obliquity (41 ka), and precession (23/19 ka) signals. The GRAPE density record, however, shows a higher response to the precessional periodicity than the magnetic susceptibility record.

For the last 4 m.y., we relied on fine tuning of the precessionrelated oscillations of the GRAPE density record to the summer insolation at $65^{\circ} \mathrm{N}$, rather than tuning the magnetic susceptibility record to obliquity, because of a higher time resolution of 19/23-ka units between each age control point. Other reasons for preferring the GRAPE density record are (1) the continuance of a strong GRAPE density signal below 111.2 mbsf c.d. (equal to $2.73 \mathrm{Ma}$ ), (2) the less pronounced high-frequency amplitude fluctuations of the magnetic susceptibility record between 1.3 and $2.7 \mathrm{Ma}$, and (3) the breakdown of the magnetic susceptibility signal at 2.73 Ma caused by the absence of IRD input during the Pliocene warm period, before the major intensification of the Northern Hemisphere glaciation (Fig. 2).

We fine-tuned the GRAPE density minima of the last 4 m.y. directly to summer insolation maxima (July) at $65^{\circ} \mathrm{N}$, assuming no phase difference. This negative correlation is indicated by the lowresolution planktonic record from Site $882(0-0.8 \mathrm{Ma})$, which clearly indicates that GRAPE density minima occur during warm stages (Fig. 2). Furthermore, the GRAPE density minima are related to IRD input minima and biogenic opal maxima during the last $2.73 \mathrm{~m}$.y., as indicated by a comparison with independent sedimentological proxy data (Rea, Basov, Janecek, Palmer-Julson, et al., 1993; Haug et al., this volume). Before the major change at $2.73 \mathrm{Ma}$, the sediments have a different composition than during the last 2.73 m.y. In the warm 


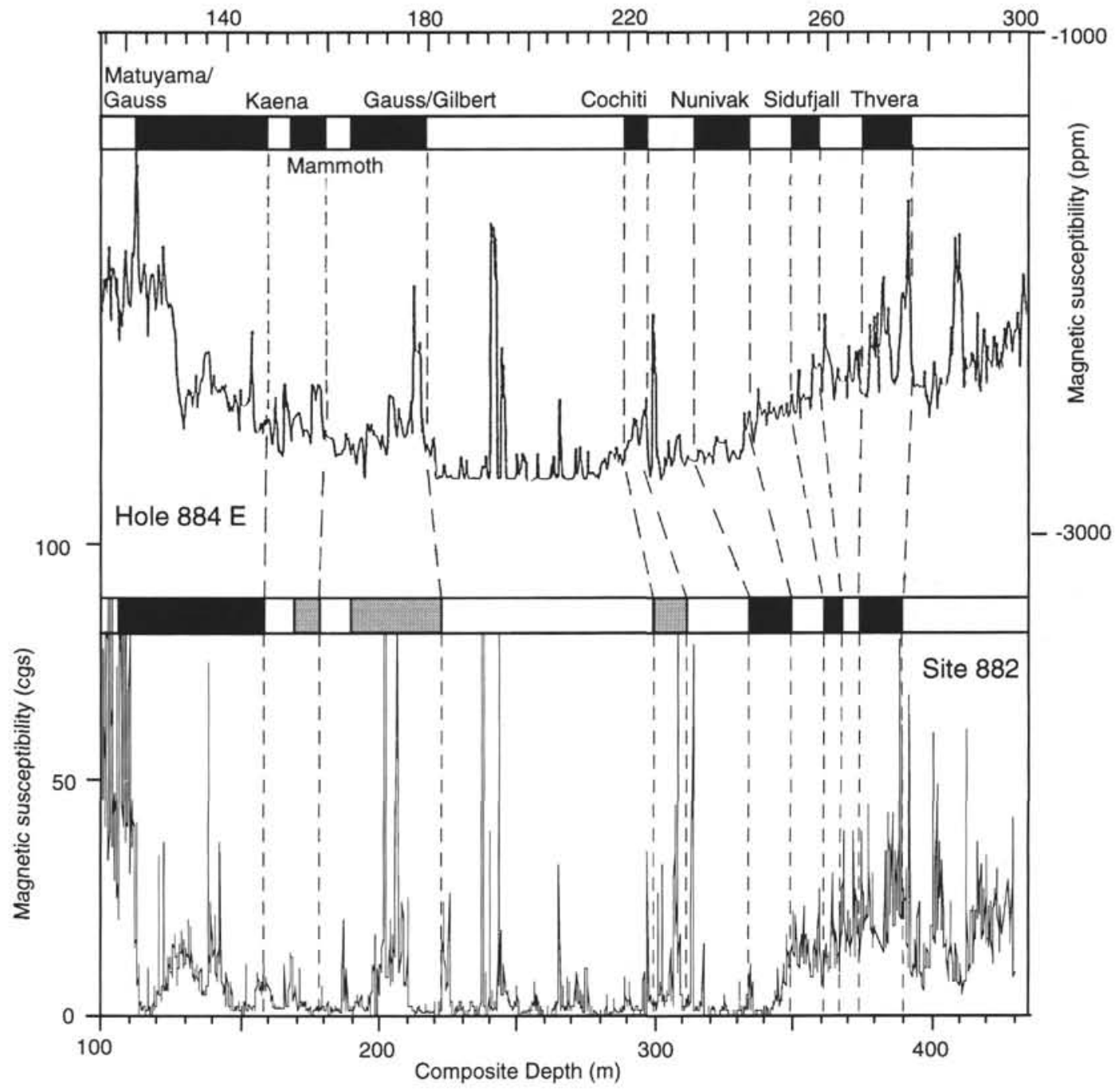

Figure 1. Comparison of magnetic susceptibility records from Sites 882 (core data) and 884 (logging data) with respect to the depth placements of the magnetic reversal boundaries. Uncertain magnetic events are shown by stippled bars.

Pliocene interval between 2.73 and $4 \mathrm{Ma}$, there is no significant IRD input. High GRAPE density values, therefore, reflect maxima in carbonate accumulation (Haug et al., this volume). The benthic and planktonic isotope records from 2.6 to $3.1 \mathrm{Ma}$ (Maslin et al., this volume) indicate that GRAPE maxima correlated with isotopic warm stages before the major change at $2.73 \mathrm{Ma}$. The result is a negative correlation of GRAPE density values to warm stages between 0 and 2.73 Ma and a positive correlation between 2.73 and $4 \mathrm{Ma}$ (Fig. 2).

Assuming zero phase differences might be an oversimplification of the true phase relationships between the GRAPE density record and the insolation record, especially for the last $2.7 \mathrm{~m}$.y. If the cyclic variations in the GRAPE record are mainly controlled by changes in ice volume that lags the insolation record by several thousand years (Imbrie and Imbrie, 1980), then the GRAPE record should also lag the insolation record. Cross-spectral analysis between the GRAPE density and the magnetic susceptibility record shows that during the last $1 \mathrm{~m} . \mathrm{y}$., both records are highly coherent and in phase at the major orbital frequencies (Fig. 3). Haug et al. (this volume) found a remarkable correlation between the magnetic susceptibility record and the siliciclastic fraction $>2 \mu \mathrm{m}$. From this, we conclude that (1) the fluctuations in the magnetic susceptibility record are a good proxy for the input of IRD and (2) the fluctuations in the GRAPE density record have a strong overprint caused by the supply of IRD. Because the supply of IRD at Site 882 is controlled by the southward advances of the subarctic sea-ice margin and is thus related to changes in arctic-ice volume, the GRAPE density record may lag the insolation record by a few thousand years during the last 2.7 m.y. However, with the absence of IRD before 2.7 Ma the phase relationships between the GRAPE record and the insolation record may have changed, because changes in biogenic opal and carbonate productivity/dissolution control the GRAPE density fluctuations. We do not yet know the true phase relationships, but this would only result in a minor error of the tuned time scale. Cross-spectral analysis between the different sediment components (biogenic opal, carbonate, IRD, etc.) at Site 882 may help to solve this problem.

The low response of the GRAPE density record to variations in orbital precession during the Olduvai Event (1.77-1.95 Ma) and between 2.45 and $2.58 \mathrm{Ma}$ (Fig. 2) did not allow fine tuning to the precession-related fluctuations of the insolation record. In contrast, significant variance existed at the obliquity band over this time interval. Therefore, we tuned the obliquity-related fluctuations of GRAPE to the obliquity component of the insolation record.

Tuning the time interval from 2.6 to $2.8 \mathrm{Ma}$ was problematic because it included the major change in the sedimentation rates and the change from an anti-phase to an in-phase relationship between the GRAPE and the insolation record associated with the dramatic drop of the GRAPE density values. The sedimentation rate of the last 2.6 m.y. was on average $4 \mathrm{~cm} / \mathrm{k} . \mathrm{y}$. and increased at the Matuyama/Gauss 
Table 2. Occurrence and ages of magnetic reversal boundaries at Site 882.

\begin{tabular}{|c|c|c|c|c|}
\hline \multirow[b]{2}{*}{ Magnetic reversals } & \multirow[b]{2}{*}{$\begin{array}{l}\text { Composite } \\
\text { depth } \\
\text { (m) }\end{array}$} & \multirow[b]{2}{*}{$\begin{array}{c}\text { Tuned age, } \\
\text { this work } \\
\text { (Ma) }\end{array}$} & \multicolumn{2}{|c|}{ Time scale (Ma) according to: } \\
\hline & & & $\begin{array}{c}\text { Shackleton } \\
\text { et al. } \\
\text { (1990) }\end{array}$ & $\begin{array}{l}\text { Hilgen } \\
\text { (1991) }\end{array}$ \\
\hline Brunhes/Matuyama & 39.30 & 0.78 & 0.78 & \\
\hline Top Jaramillo & 48.97 & 0.99 & 0.99 & \\
\hline Base Jaramillo & 53.50 & 1.08 & 1.07 & \\
\hline Top Olduvai & 81.59 & 1.77 & 1.77 & \\
\hline Base Olduvai & 84.42 & 1.95 & 1.95 & \\
\hline Matuyama/Gauss & 105.94 & 2.61 & 2.60 & \\
\hline Top Ḱaena & 157.70 & 3.06 & & 3.04 \\
\hline Top Mammoth & 178.09 & 3.23 & & 3.22 \\
\hline Gauss/Gilbert & 222.32 & 3.58 & & 3.58 \\
\hline Top Cochity & 298.74 & & & 4.18 \\
\hline Base Cochity & 310.84 & & & 4.29 \\
\hline Top Nunivak & 333.38 & & & 4.48 \\
\hline Base Nunivak & 348.68 & & & 4.62 \\
\hline Top Sidufjall & 360.77 & & & 4.80 \\
\hline Base Sidufjall & 367.68 & & & 4.89 \\
\hline Top Thvera & 373.83 & & & 4.98 \\
\hline Base Thvera & 388.72 & & & 5.23 \\
\hline
\end{tabular}

boundary to a mean value of $14 \mathrm{~cm} / \mathrm{k} . \mathrm{y}$. before that time, if the magnetic reversal boundaries are taken as initial age control. However, the change in the sedimentation rates occurred along with the dramatic drop in the GRAPE density values (Fig. 2) and the increase in the biogenic opal values (Haug et al., this volume) about $5.4 \mathrm{~m}$ deeper in the sediment record (111.35 mbsf c.d.) than the Matuyama/ Gauss boundary. This is clearly indicated by the dominance of the obliquity-related cycles in the GRAPE record. Below $111.35 \mathrm{~m}$, cycles with a wavelength (in depth terms) of 5-6 m dominated and then decreased to about $2 \mathrm{~m}$ above the major change. After tuning, the switch in the phase relationship occurred between 2.7 and $2.75 \mathrm{Ma}$. This is confirmed by the planktonic isotope records from 2.6 to 3.1 $\mathrm{Ma}$ at Site 882 (Maslin et al., this volume). The placement of the glacial isotope Stage G6 at 2.73 Ma and the interglacial Stage G7 at 2.77 Ma matched with the global oxygen isotope stratigraphy (Tiedemann et al., 1994).

We used the following independent evidence to test the correlation between the insolation and the GRAPE density record for the last 4 m.y.:

1. A tuning in the precessional band (0-2.73 Ma) improved the variance density over all the main orbital frequencies and indicates high coherencies with the $65^{\circ} \mathrm{N}$ July insolation record, as indicated by cross-spectral analysis. The strong concentration of spectral power at the eccentricity ( 400 and $100 \mathrm{ka}$ ) and obliquity ( $41 \mathrm{ka}$ ) periods after tuning the GRAPE density precession-related oscillations corroborates the tuning (Fig. 2).

2. After tuning the record, we calculated the sedimentation rates between each adjusted age control point of orbital variation (Table 3 ). Extreme deviations in the sedimentation rate between age control points are not very likely. The sedimentation rates are found to vary from 10 to $19 \mathrm{~cm} / \mathrm{k} . y$. between 4 and $2.73 \mathrm{Ma}$, and from 2 to $9 \mathrm{~cm} / \mathrm{k} . \mathrm{y}$. during the last 2.73 m.y. Even lower sedimentation rates of 1-2 $\mathrm{cm} /$ k.y. mark the Olduvai Event (Fig. 2).

3. For the last 4 m.y., the precession component of the GRAPE density record was isolated by filtering and compared to orbital precession (Fig. 2). We found a remarkable similarity of phase and amplitude variations between the 22-ka filter output from the GRAPE density record and orbital precession during the last $4 \mathrm{~m}$.y., especially for the last $1.8 \mathrm{~m} . \mathrm{y}$. In addition, the $41-\mathrm{ka}$ filter output from the GRAPE density record also provided good similarities to the orbital obliquity in both phase and amplitude over the last 4 m.y., with the best match found between 1 and $3.6 \mathrm{Ma}$ (Fig. 2).

4. Tuning the precessional component of the GRAPE density record to the insolation record also improves the spectral power of the magnetic susceptibility signal over all the main orbital frequencies. The time intervals $0-1 \mathrm{Ma}$ and 2-3 Ma indicate significant coheren-
Table 3. Age control points of the tuned age-depth model at Site $\mathbf{8 8 2}$ for the last 4 m.y.

\begin{tabular}{|c|c|c|c|c|c|c|c|}
\hline $\begin{array}{l}\text { Composite } \\
\text { depth }(m)\end{array}$ & $\begin{array}{l}\text { Age } \\
\text { (ka) }\end{array}$ & $\begin{array}{l}\text { Composite } \\
\text { depth }(\mathrm{m})\end{array}$ & $\begin{array}{l}\text { Age } \\
\text { (ka) }\end{array}$ & $\begin{array}{c}\text { Composite } \\
\text { depth (m) }\end{array}$ & $\begin{array}{l}\text { Age } \\
\text { (ka) }\end{array}$ & $\begin{array}{l}\text { Composite } \\
\text { depth }(m)\end{array}$ & $\begin{array}{l}\text { Age } \\
(\mathrm{ka})\end{array}$ \\
\hline 0.00 & 0 & 43.75 & 884 & 81.44 & 1760 & 148.54 & 3007 \\
\hline 0.92 & 15 & 44.22 & 894 & 82.00 & 1799 & 152.34 & 3030 \\
\hline 3.95 & 70 & 45.80 & 925 & 82.29 & 1812 & 156.57 & 3054 \\
\hline 6.22 & 103 & 46.85 & 945 & 82.52 & 1832 & 159.91 & 3075 \\
\hline 6.96 & 115 & 47.87 & 957 & 82.70 & 1845 & 167.12 & 3146 \\
\hline 7.59 & 137 & 48.74 & 979 & 83.38 & 1904 & 170.08 & 3167 \\
\hline 8.78 & 160 & 49.45 & 1000 & 83.63 & 1919 & 172.99 & 3197 \\
\hline 11.39 & 187 & 51.69 & 1050 & 84.11 & 1947 & 178.69 & 3231 \\
\hline 12.48 & 219 & 52.53 & 1061 & 85.36 & 1975 & 181.33 & 3252 \\
\hline 12.74 & 229 & 53.05 & 1070 & 86.69 & 2012 & 185.46 & 3279 \\
\hline 13.64 & 251 & 53.72 & 1082 & 87.62 & 2052 & 189.93 & 3318 \\
\hline 14.99 & 275 & 54.46 & 1104 & 88.71 & 2086 & 194.71 & 3347 \\
\hline 16.52 & 301 & 55.75 & 1136 & 89.61 & 2130 & 195.84 & 3359 \\
\hline 18.30 & 344 & 56.70 & 1178 & 90.62 & 2171 & 198.27 & 3391 \\
\hline 19.41 & 362 & 57.97 & 1206 & 91.74 & 2190 & 201.18 & 3411 \\
\hline 20.34 & 372 & 59.03 & 1224 & 93.18 & 2216 & 203.93 & 3433 \\
\hline 21.05 & 397 & 60.32 & 1254 & 95.54 & 2252 & 205.20 & 3443 \\
\hline 22.06 & 417 & 61.38 & 1273 & 97.22 & 2311 & 207.34 & 3464 \\
\hline 23.89 & 452 & 62.40 & 1307 & 98.25 & 2374 & 208.84 & 3475 \\
\hline 24.72 & 474 & 63.54 & 1337 & 100.33 & 2411 & 212.96 & 3506 \\
\hline 26.12 & 494 & 64.47 & 1358 & 101.09 & 2429 & 216.11 & 3526 \\
\hline 27.56 & 515 & 65.11 & 1389 & 101.56 & 2449 & 218.59 & 3548 \\
\hline 28.21 & 545 & 66.49 & 1422 & 102.52 & 2489 & 222.52 & 3579 \\
\hline 28.85 & 565 & 66.89 & 1434 & 103.39 & 2534 & 226.70 & 3604 \\
\hline 29.29 & 588 & 67.32 & 1451 & 104.80 & 2580 & 230.66 & 3624 \\
\hline 29.81 & 609 & 67.83 & 1465 & 105.73 & 2604 & 234.03 & 3643 \\
\hline 31.08 & 631 & 68.40 & 1482 & 106.12 & 2625 & 238.01 & 3679 \\
\hline 31.55 & 642 & 68.90 & 1504 & 107.56 & 2650 & 240.91 & 3698 \\
\hline 32.56 & 659 & 70.26 & 1538 & 108.21 & 2672 & 244.41 & 3720 \\
\hline 33.89 & 681 & 71.81 & 1566 & 109.43 & 2695 & 246.93 & 3741 \\
\hline 36.66 & 723 & 72.30 & 1586 & 111.18 & 2729 & 249.79 & 3764 \\
\hline 37.92 & 758 & 73.39 & 1605 & 113.81 & 2753 & 252.33 & 3791 \\
\hline 38.65 & 776 & 74.75 & 1625 & 116.74 & 2785 & 254.72 & 3813 \\
\hline 39.23 & 786 & 75.47 & 1645 & 120.07 & 2810 & 257.19 & 3834 \\
\hline 39.88 & 814 & 76.89 & 1674 & 124.15 & 2844 & 259.97 & 3855 \\
\hline 40.46 & 825 & 78.42 & 1697 & 127.85 & 2878 & 263.73 & 3883 \\
\hline 41.00 & 842 & 78.75 & 1708 & 131.27 & 2905 & 264.94 & 3895 \\
\hline 41.94 & 853 & 79.33 & 1718 & 136.60 & 2937 & 270.02 & 3929 \\
\hline 42.99 & 874 & 79.70 & 1728 & 144.45 & 2981 & 275.41 & 3966 \\
\hline
\end{tabular}

cies with the insolation record at the main orbital frequencies (Fig. 2). Over these time intervals, the 41-ka filter output from the magnetic susceptibility record is generally in phase with the variations in orbital obliquity. Between 2.73 and $2.5 \mathrm{Ma}$, strong maxima in ice-rafted debris as indicated by the magnetic susceptibility record occur during the first pronounced glacial oxygen isotope Stages 96-100 and 104G6, along with the major intensification of the Northern Hemisphere glaciation. This is very likely.

From 1 to $2 \mathrm{Ma}$, however, the tuning did not improve the magnetic susceptibility response at the obliquity and the precession bands. The spectrum is dominated by a 333-ka and a 71-ka cycle. The 41-ka filter output shows a mismatch with orbital obliquity from 1.5 to $1.8 \mathrm{Ma}$ and from 1.2 to $1.3 \mathrm{Ma}$. This may indicate that there is probably still a mistake in the stratigraphy. The mismatch at $1.25 \mathrm{Ma}$ results from a strong magnetic susceptibility maximum. Such a maximum is typical for an ash layer that has probably been overlooked. However, the core photos give no clear evidence for an ash layer (Rea, Basov, Janecek, Palmer-Julson, et al., 1993).

Before $2.73 \mathrm{Ma}$, the magnetic susceptibility signal is greatly reduced because of the absence of IRD input and does not show any remarkable variations (Fig. 2).

5. Over the last 0.8 m.y., the variations of cold and warm stages as indicated by the low-resolution planktonic $\delta^{18} \mathrm{O}$ record from Site 882 corroborates the systematically tuned stratigraphy (Fig. 2). The planktonic isotope record between 2.65 and $3.1 \mathrm{Ma}$ (Maslin et al., this volume) confirms the tuning of GRAPE density maxima to isolation maxima between 2.73 and $4 \mathrm{Ma}$.

\section{CONCLUSIONS}

We developed a cycle stratigraphy for the last 4 m.y. for Site 882 in the northwest Pacific based on tuning the GRAPE density record. 
A

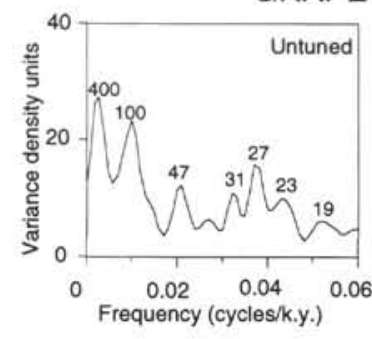

GRAPE (0-1 Ma)

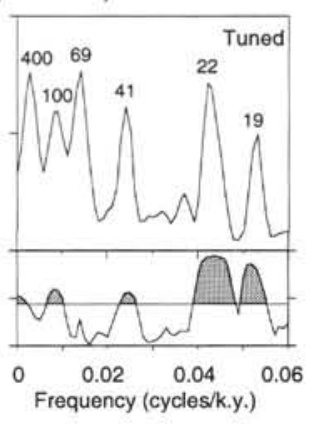

Magnetic susceptibility (0-1 Ma)
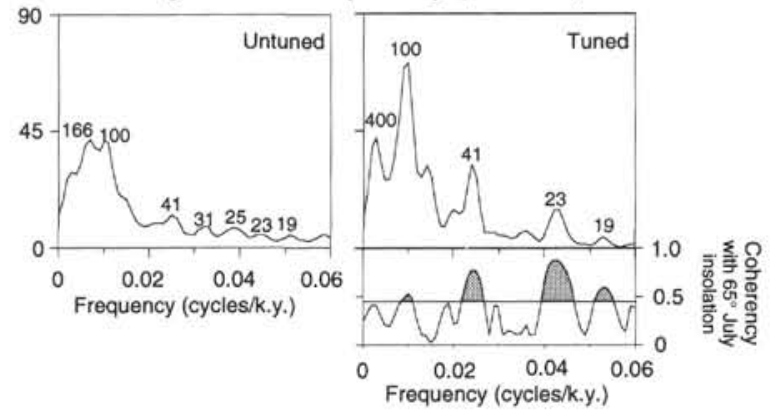
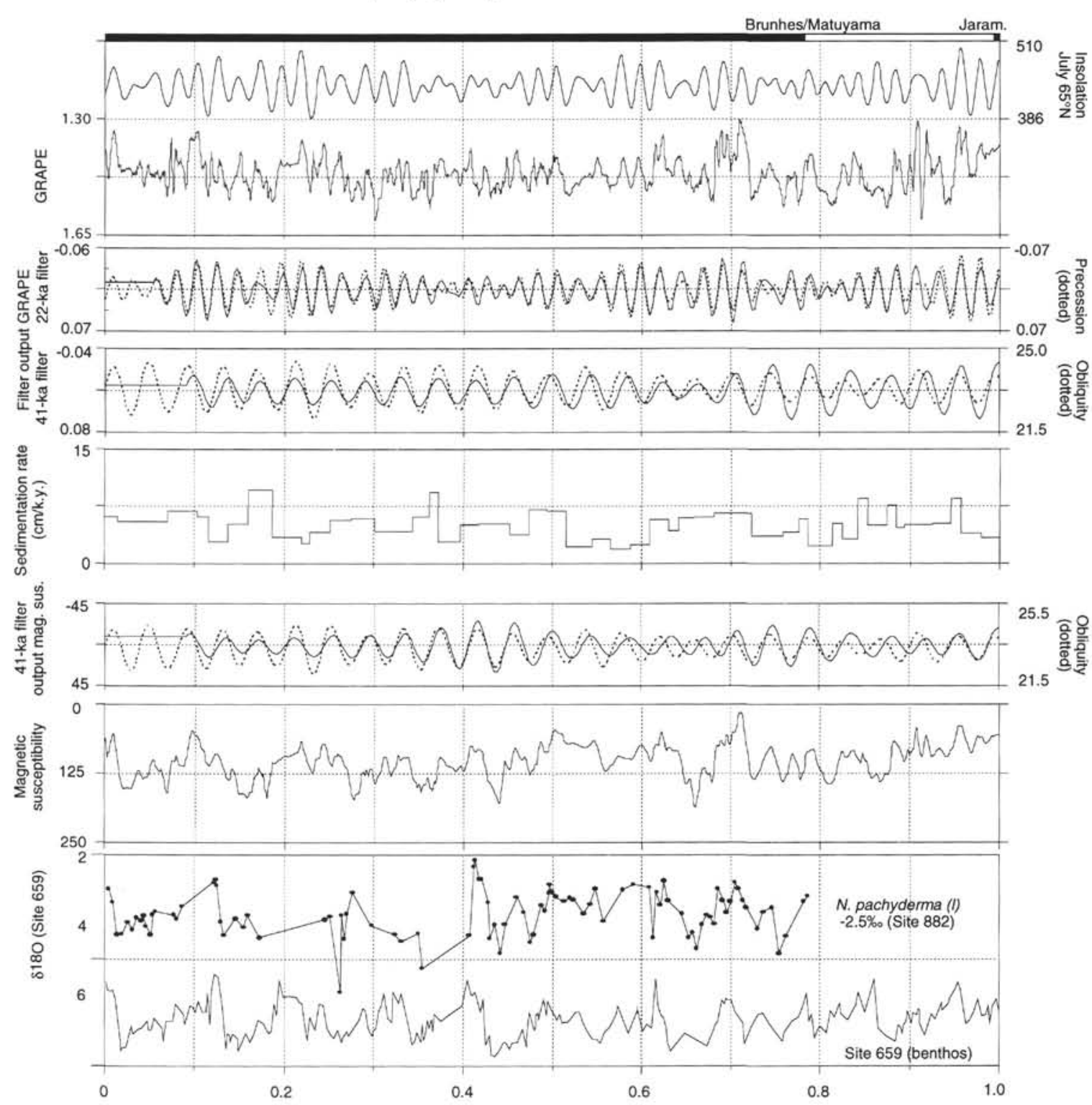

Age (Ma)

Figure 2. Summary of Site 882 records over the last 4 m.y. A. 0-1 Ma. B. 1-2 Ma. C. 2-3 Ma. D. 3-4 Ma. Plots indicate, magnetic reversal boundaries, summer insolation at $65^{\circ} \mathrm{N}$, GRAPE density and its 41 - and 22-ka filter outputs (solid) compared to the orbital obliquity and precession (dashed), sedimentation rates, magnetic susceptibility and its 41 -ka filter output (solid) compared to the orbital obliquity (dashed), planktonic and benthic $\delta^{18} \mathrm{O}$ records for the last $1 \mathrm{~m} . \mathrm{y}$. The 41 (22-) ka filter has a central frequency of $0.024(0.045)$ cycles/k.y. and a bandwidth of $0.022(0.036)$ cycles/k.y. Note that the GRAPE density, the magnetic susceptibility, and their filter outputs are inverted. The benthic $\delta^{18} \mathrm{O}$ record from Site $659(0-4 \mathrm{Ma})$ has been included for comparison. The stratigraphy for the last 2.73 m.y. is based on tuning GRAPE minima to summer insolation maxima and vice versa from 2.73 to 4 Ma. Frequency spectra from tuned and untuned GRAPE and magnetic susceptibility records, as well as cross-spectral coherencies between the tuned records and the summer insolation record are plotted on top of the figure. 
B

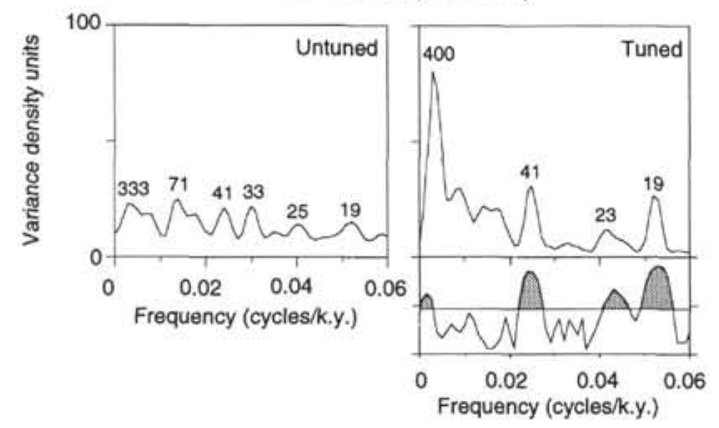

Magnetic susceptibility (1-2 Ma)
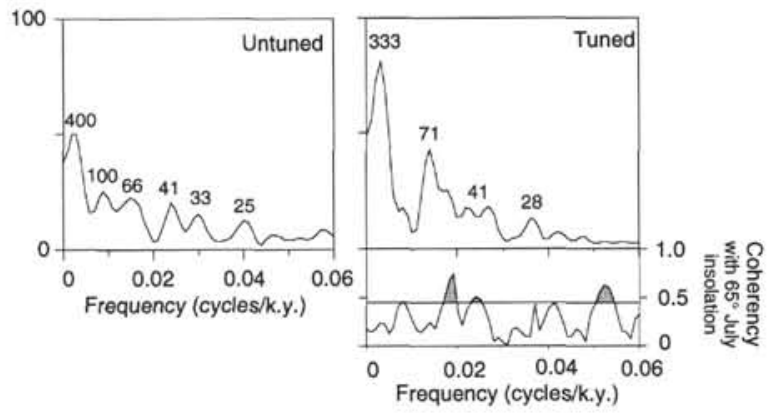
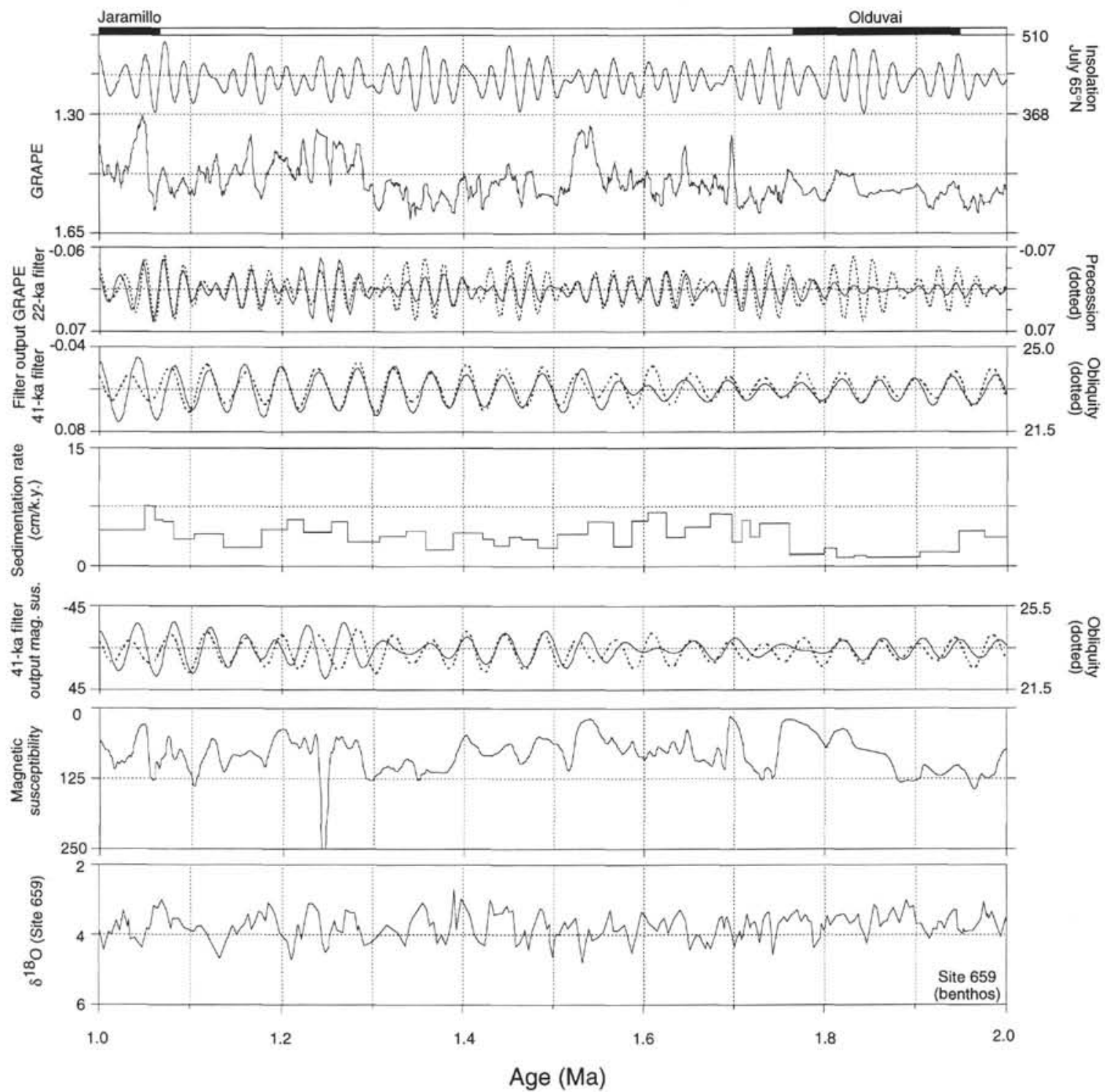

Figure 2 (continued).

Our results indicate that the GRAPE density record from Site 882 can be calibrated accurately to the precessional component of the summer insolation at $65^{\circ} \mathrm{N}$ during the last $4 \mathrm{~m} . \mathrm{y}$. This tuning resulted in an independent calibration of the magnetic susceptibility record. From 0 to $0.8 \mathrm{Ma}$ and from 2.6 to $3.1 \mathrm{Ma}$, low-resolution planktonic $\delta^{18} \mathrm{O}$ records from Site 882 (Haug et al., this volume; Maslin et al., this volume) corroborate the tuned stratigraphy.
Tuning the precession-related fluctuations in the GRAPE density to the insolation record increased the spectral density over all the main orbital frequencies for both the magnetic susceptibility and the GRAPE density records. Cross-spectral analysis between the GRAPE density and the magnetic susceptibility (indicative of the input of ice-rafted debris) indicated an in-phase relationship over the main orbital frequencies. 
C

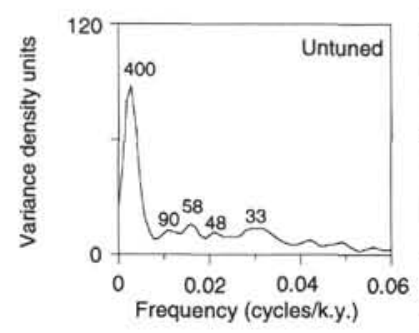

GRAPE (2-2.7 Ma)

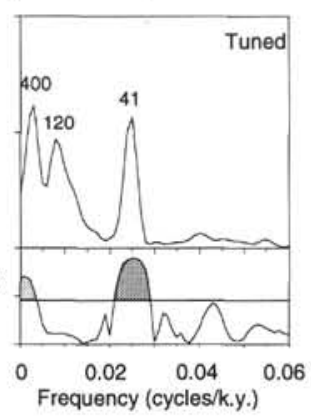

Magnetic susceptibility (2-2.7 Ma)
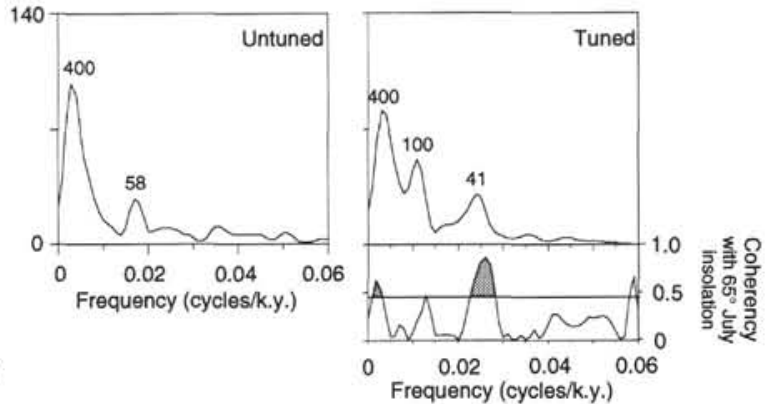

Matuyama/Gauss
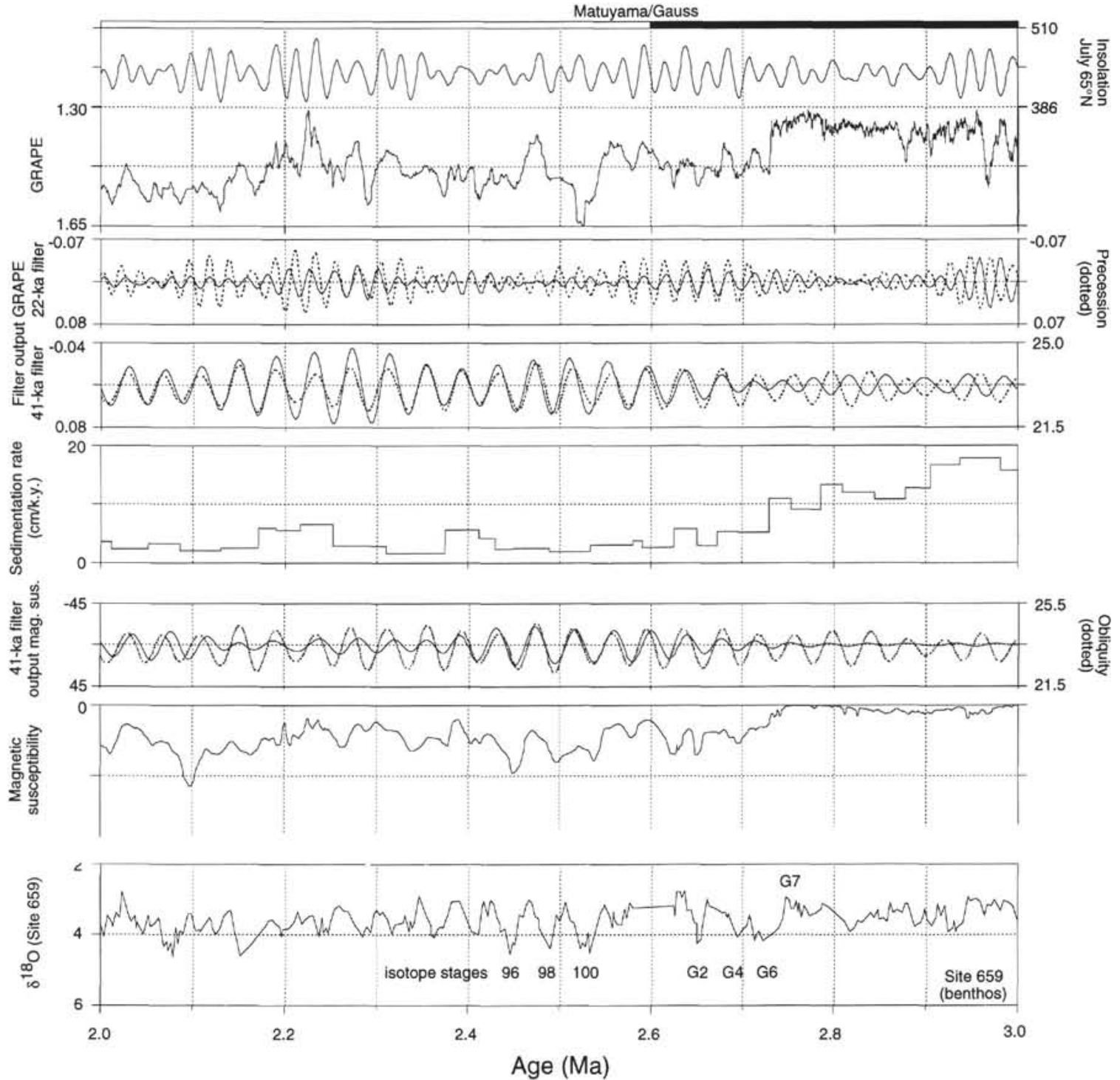

Figure 2 (continued).

Precessional periods dominated the GRAPE density spectrum during the last $1 \mathrm{~m} . \mathrm{y}$. and between 2.7 and $4 \mathrm{Ma}$. From 1 to $2.7 \mathrm{Ma}$ the GRAPE density response to orbital precession decreased, whereas the response to orbital obliquity increased and remained strong from 2.7 to $4 \mathrm{Ma}$. A significant 400 -ka cycle occurred during the last 2.7 m.y. Surprisingly for the last $1 \mathrm{~m}$.y. was the low power at the $100-\mathrm{ka}$ period in the GRAPE record. In contrast, the magnetic susceptibility record was dominated by the 100 - and 41 -ka cycles during the last 1 m.y., whereas the response to precessional forcing was minor. This kind of spectrum is very similar to that of the global oxygen isotope record. This suggests that the magnetic susceptibility record via the input of IRD is mainly controlled by changes in ice volume, whereas the GRAPE density spectrum might have a strong overprint of additional forcing mechanisms. Fluctuations in the biogenic opal content 
D

GRAPE (2.8-4 Ma)
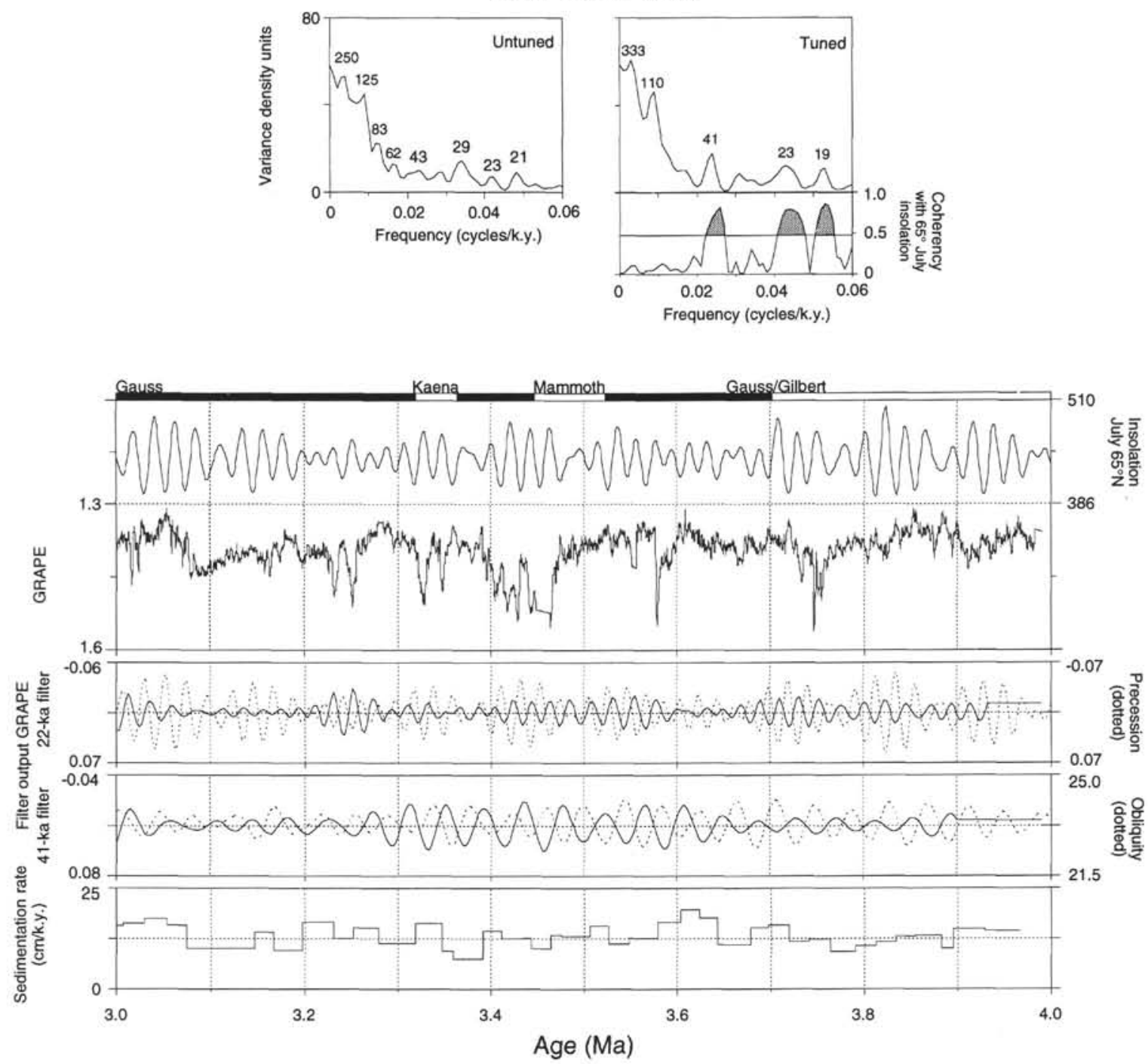

Figure 2 (continued).

(Haug et al., this volume) may be responsible for the strong precessional response in the GRAPE density record, because carbonate accumulation occurred only sporadic during the last $1 \mathrm{~m}$.y. Precessional forced changes in the supply of nutrients into the subarctic gyre off Kamchatka (Dodimead et al., 1963) may have triggered changes in productivity at Site 882 . However, this can be tested by spectral analysis of the biogenic opal record.

The goal of this work was to generate a high-resolution stratigraphy at Site 882 that enables a comparison of northwest Pacific proxy records to other high-resolution oceanic records for further paleoceanographic and paleoclimatic investigations.

\section{ACKNOWLEDGMENTS}

We thank the Ocean Drilling Program and the shipboard scientists of ODP Leg 145 who made this study possible. We wish to thank Steven Clemens, Mark Maslin, T.C. Moore, David Rea, Janalisa Soltis, and Rainer Zahn for the reviews and constructive criticisms that helped to improve the manuscript. This study was generously supported by the Deutsche Forschungsgemeinschaft.

\section{REFERENCES*}

Berger, A., and Loutre, M.F., 1991. Insolation values for the climate of the last 10 million years. Quat. Sci. Rev., 10:297-317.

Berggren, W.A., Kent, D.V., Flynn, J.J., and Van Couvering, J.A., 1985. Cenozoic geochronology. Geol. Soc. Am. Bull., 96:1407-1418.

Dodimead, A.J., Favorite, F., and Hirano, T., 1963. Salmon of the North Pacific, II: review of the oceanography of the subarctic Pacific region. Bull. Int. N. Pac. Fisheries Comm., 13:1-195.

Hilgen, F.J., 1991. Extension of the astronomically calibrated (polarity) time scale to the Miocene/Pliocene boundary. Earth Planet. Sci. Lett., 107:349368.

Imbrie, J., Hays, J.D., Martinson, D.G., McIntyre, A., Mix, A.C., Morley, J.J., Pisias, N.G., Prell, W.L., and Shackleton, N.J., 1984. The orbital theory of Pleistocene climate: support from a revised chronology of the marine $\delta^{18} \mathrm{O}$ record. In Berger, A., Imbrie, J., Hays, J., Kukla, G., and Saltzman, B. (Eds.), Milankovitch and Climate (Pt. 1): Dordrecht (D. Reidel), 269-305.

\footnotetext{
Abbreviations for names of organizations and publications in ODP reference lists follow the style given in Chemical Abstracts Service Source Index (published by American Chemical Society).
} 
Imbrie, J., and Imbrie, J.Z., 1980. Modeling the climatic response to orbital variations. Science, 207:943-953.

Rea, D.K., Basov, I.A., Janecek, T.R., Palmer-Julson, A., et al., 1993. Proc. ODP, Init. Repts., 145: College Station, TX (Ocean Drilling Program).

Shackleton, N.J., Berger, A., and Peltier, W.R., 1990. An alternative astronomical calibration of the lower Pleistocene timescale based on ODP Site 677. Trans. R. Soc. Edinburgh: Earth Sci., 81:251-261.

Shackleton, N.J., Hall, M.A., and Pate, D., 1995. Pliocene stable isotope stratigraphy of Site 846. In Pisias, N.G., Mayer, L.A., Janecek, T.R.,
Palmer-Julson, A., and van Andel, T.H. (Eds.), Proc. ODP, Sci. Results, 138: College Station, TX (Ocean Drilling Program), 337-355.

Tiedemann. R., Sarnthein, M., and Shackleton, N.J., 1994. Astronomic time scale for the Pliocene Atlantic $\delta^{18} \mathrm{O}$ and dust flux records of ODP Site 659. Paleoceanography, 9:619-638.

Date of initial receipt: 11 April 1994

Date of acceptance: 7 October 1994

Ms 145SR-124
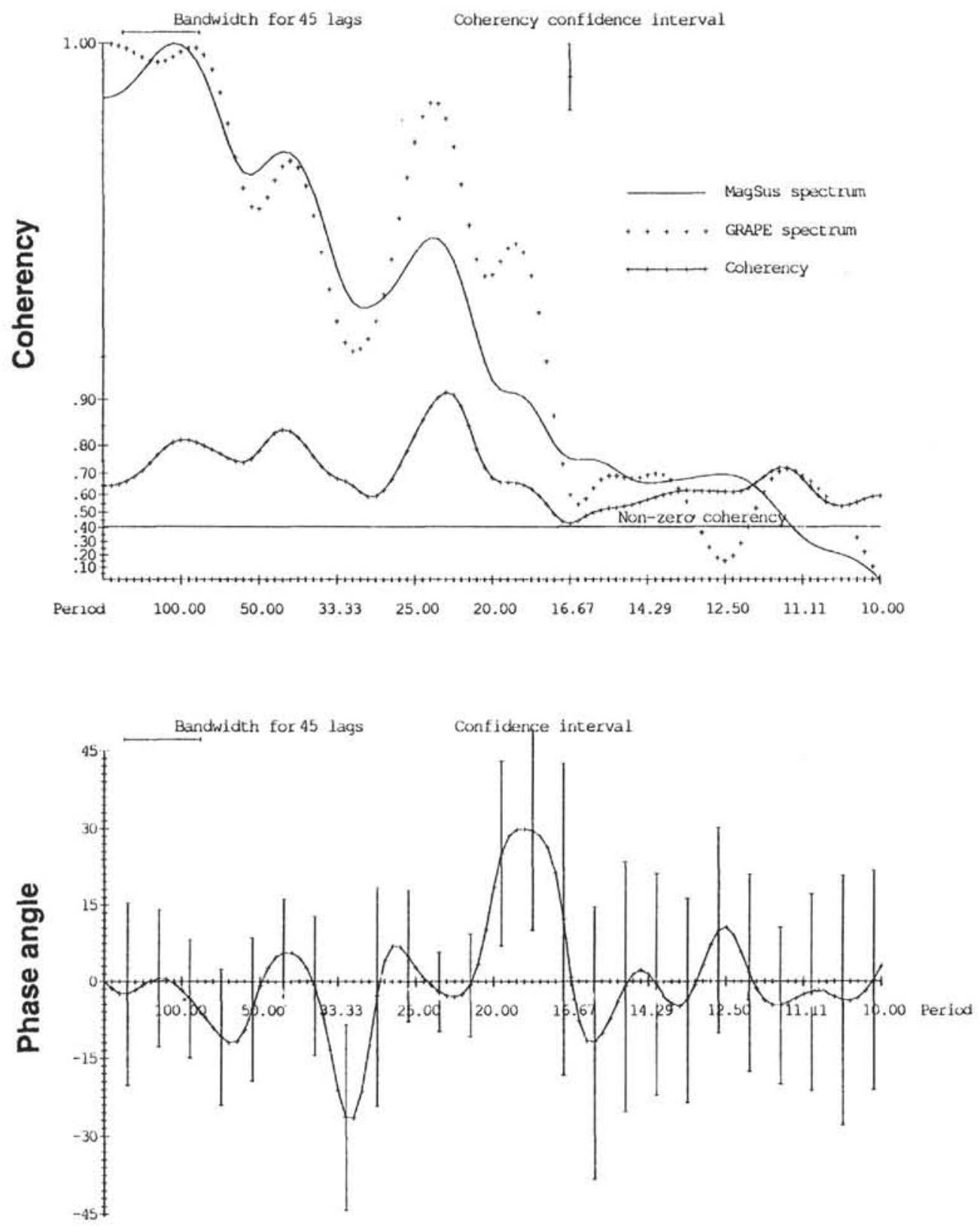

Figure 3. Spectral density, cross coherency, and phase relationship between the magnetic susceptibility and GRAPE density records from northwest Pacific Site 882 for the last $1 \mathrm{~m} . \mathrm{y} .(N=334$; time step $=3 \mathrm{k} . \mathrm{y}$; 45 lags). Note that both records are in phase at the eccentricity ( $100 \mathrm{ka})$, obliquity ( $41 \mathrm{ka})$, and precession ( 23 ka) bands. 